\title{
PARP2 Gene Mutation
}

National Cancer Institute

\section{Source}

National Cancer Institute. PARP2 Gene Mutation. NCI Thesaurus. Code C154148.

A change in the nucleotide sequence of the PARP2 gene. 